\title{
DOMESTIC VIOLENCE AGAINST WOMEN AND ITS IMPACT ON CHILDREN'S SCHOOL PERFORMANCE
}

\author{
Ediane Alves, \& Paulo Prado \\ Graduate Program in Teaching and Formative Processes, São Paulo State University (Unesp) (Brazil)
}

\begin{abstract}
This research addressed the issue of domestic violence investigating whether and how it affects the school performance of the child who witnesses episodes of violence against the mother in the home. Personal characteristics and other environments in which these children and adolescents are inserted in, such as family, school and community interact with each other and can influence their school performance. Because the school is the second most common space for children, it is in it where family environment is expressed. The main objective of this study was to analyze whether and how domestic violence experienced by children affects their school performance. The data were collected throughout documentary research, one analyzing the information recorded in the files of the Reference and Service Center for Women (CRAM in Portuguese) and the Municipal Education Secretariat (SME). Records were selected from 20 children regularly enrolled in elementary public schools, whose mothers sought the services of CRAM. The dependent variable was school grades, which were analyzed according to a repeated measures design: during the occurrence of domestic violence episodes and after these episodes have ceased. Analyzes were also conducted with the aim of verifying possible effects of other variables, such as school attendance, family socioeconomic status and mothers education level. The results showed that the students had lower school performance after the end of the episodes of violence. No effects of other variables were observed. Factors related to the phenomenon are discussed as possible causes: separation from the father, change of address, custody's change and others. Considering that the casuistry of this study was composed of students from low-income families, the results point to a kind of "Matthew effect", that is, a relationship between violence, poverty and ignorance in which everyone feeds each other forming a cycle quite hard to break. Therefore, it is necessary that public policies be formulated in the scope of education so that students who experience domestic violence receive specialized attention aiming at realizing their learning potential.
\end{abstract}

Keywords: Domestic violence, violence against women, school performance, elementary school, basic education.

\section{Introduction}

Domestic violence against women is a worldwide phenomenon that is not restricted to ethnicity, socioeconomic status, age or religion. Most domestic violence is marital and, in its majority, the victims are women. Given that the phenomenon in question occurs in the context of home, one must to consider that this is the child's first social nucleus, therefore, its natural environment for growth and development. However, unfortunately the family is not always able to adequately fulfill its functions and, according to the Latin American Faculty of Social Sciences (FLACSO, 2015), 27.1\% of femicides in Brazil occur at home. Thus, the environment that should be a safe place for the full development of children and adolescents becomes just the opposite. The investigation reported here was conducted in order to find out how domestic violence against women affects the children's academic performance.

\section{Children and witnessed domestic violence}

Many factors contribute to school success or failure. They are internal, such as cognition, temperament, personality traits, and external, such as social, cultural, family affection and many others. If the child is inserted in a friendly parental environment, with parents who have a good relationship with each other and with the children, the likelihood of them presenting appropriate behaviors and good school performance is greater. Rohenkohl and Castro (2012) found that children of couples with a high level of 
conflict and low affection tend to have more behavioral and emotional problems compared to children from families whose parents have fewer conflicts and are more affectionate. Although the adversities of the family potentially trigger psychological and cognitive disorders that can affect school performance, on the other hand there are researches whose results (Brancalhone et al., 2004; Ghazarian and Buehler, 2010; Harold et al., 2007;) show that domestic violence solely did not affect adversely the school performance of children exposed to it.

\section{Method}

Present research was approved by Research Ethics Committee of São Paulo State University (Unesp), Institute of Biosciences, Modern Languages and Exact Sciences, Campus of São José do Rio Preto, Brazil. The information sources were Reference and Care Center for Women (CRAM, in Portuguese) and the Municipal Department of Education (SME), whose professionals in charge signed a free and informed consent term authorizing collecting data.

We analyzed the school performance of students regularly enrolled in elementary school from 2013 to 2018. All of them were children exposed to episodes of domestic violence committed against their mother by respective marital partner. Their exposure to such episodes was, therefore, not as victims, but as witnesses, with some exceptions described below. The dependent variables were grades and school attendance. The sources of information were CRAM's archives and SME's school reports. It is, therefore, a documentary research.

The inclusion criteria were: I- The woman broken the cycle of domestic violence; II- During the school periods observed, the child should be enrolled in Elementary School in the municipal education network.

\subsection{Casuistry and procedure}

The information extracted from the CRAM's and the SME's archives were recorded in a form elaborated by the authors, which consists of 32 items, subdivided into: mother's, violence perpetrator's and child's data. Initially, we collected data of 43 children. However, 23 of them did not meet at least one of the inclusion criteria. Thus, this number was reduced to 20 students ( 9 females) with ages varying from 8 to 13 years old when the mother resorted to CRAM services, all from low-income families.

As described below, we adopted a repeated measures design. So our definition of "during" and "after" violence episodes refers, respectively, to the search for CRAM services by the mother and to the interruption of violence resulting from the couple's divorce.

\subsection{Data analysis}

A repeated measures design was adopted to analyze the data at two different moments: during the occurrence of domestic violence episodes (T1), and after its end (T2). As the data did not present a normal distribution, we used non-parametric statistical tests. The package used was BioEstat (5.0). Comparison between the grades and the attendance in both moments was performed applying the Wilcoxon Test. For the analysis of possible influences of some other factors on school performance, we considered only the T1 grades. The Median Test was applied to verify a possible effect of the family's socioeconomic level on the students' school performance. In addition, the Mann-Whitney test was applied to verify the impact of the mother's schooling on the children's school performance. The school grades analyzed were its respective annual averages in Portuguese Language, Mathematics and Sciences, that is, the sum of the bimonthly grades divided by four. As for school attendance, the total number of absences in the analyzed period was also considered.

\section{Results}

During the violence episodes (T1), students attended from second to seventh grade. Collecting data was conducted about one year after such episodes have ceased (T2), when the students attended from third to ninth grade. At this time, 15 children lived with their mother, one with their father and four with their grandmother. Four students, besides to witnessing episodes of violence also suffered it directly in one or more of its following modalities: physical, psychological, sexual and negligence. About school performance, unlike scores produced by standardized tests, school grades are assigned through individual and idiosyncratic procedures, therefore subject to greater subjectivity and variability. As a way to check its consistency, we use correlation analysis. As a whole, considering the grades in T1 as well in T2, the observed Spearman's $\rho$ was from .79 to $.94(p<.0001)$. There is, therefore, a high degree of consistency in the grades assigned by the different teachers, that is, in the evaluation they make about their students' 
academic performance, which gives us certain peace of mind to use them as the relevant data of this study. We analyzed the possible effects of two independent variables on the students' school performance: the mothers' level schooling and the families' socioeconomic level. None of them had any influence on the dependent variable. Similarly, no significant correlations were found between school performance after the end of episodes of domestic violence and the time (in years) of exposure to them (Portuguese language: $\rho=-.242 ; p>.05$; Mathematics: $\rho=-.113 ; p>.05$ and Sciences: $\rho=-.046 ; p>.05)$. Finally, no significant differences were found between students' absences during and after cessation of violence episodes $(Z=.0991 ; \mathrm{p}>.05)$. By the way, there were also no differences in school grades due to the number of absences, comparing the periods during and after episodes of domestic violence $(Z=1.6$; $\mathrm{p}=.12$ ). As for the difference in school performance during (T1) and after (T2) episodes of domestic violence, Wilcoxon test showed significant differences in Mathematics $(Z=2.542 ; \mathrm{p}=.01)$ and Sciences $(Z=2.131 ; p=.03)$, but not in Portuguese $(Z=1.757 ; p=.07)$. Figure 1 shows the comparison between students' grades in the two periods and the performance of the students who directly suffered domestic violence. In general, there is a decrease in grades after the violence ceased. Diamonds surrounded by dashed line circle represent students who, in addition to having witnessed episodes of domestic violence, also suffered it directly. Visual inspection suggests that there is no marked drop in the performance of these students compared to those who have not suffered violence, except students 9 and 17.

Figure 1. Grades obtained during and after violence ceases, with emphasis on students who, in addition to exposure to domestic violence directly suffered some type of violence.

\section{DURING}

\section{Portuguese Language}
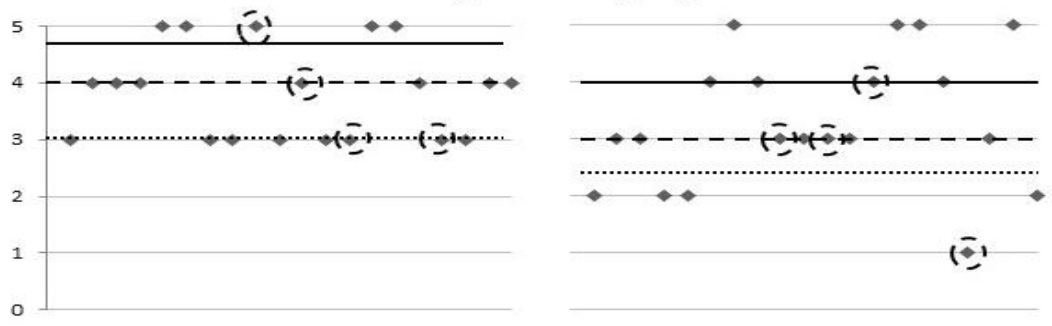

Mathematics
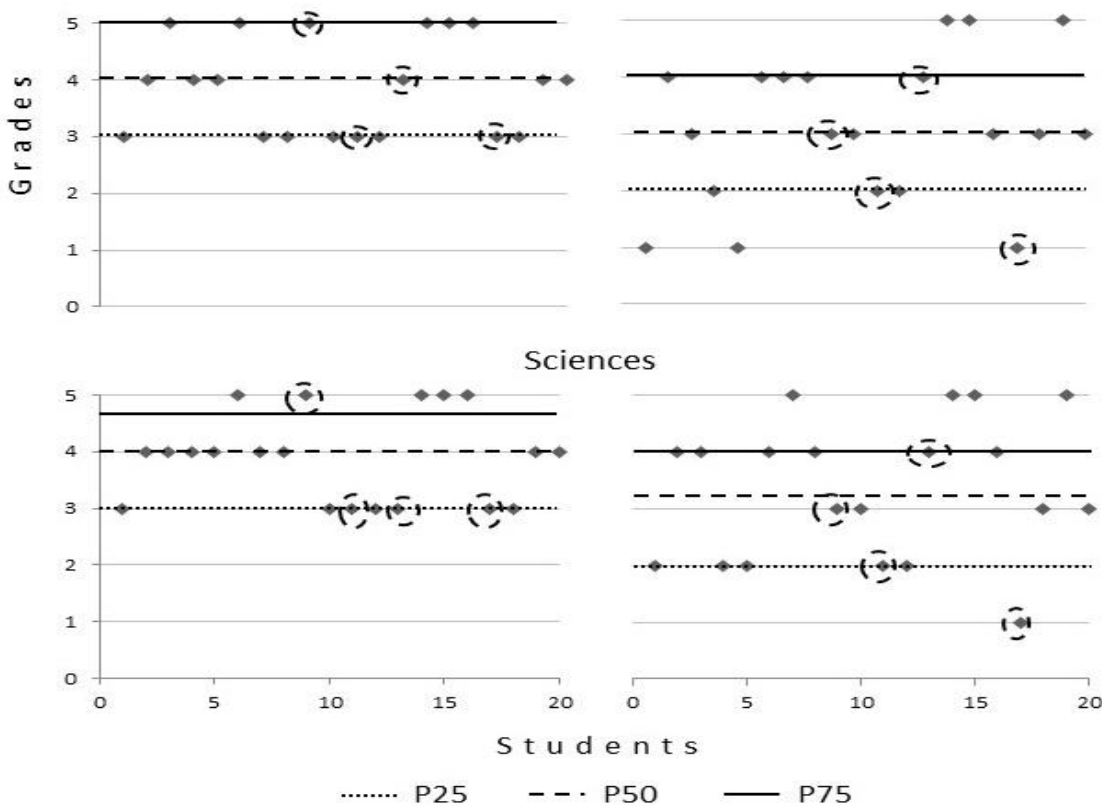

\section{Discussion}

Contrary to expectations, the end of episodes of domestic violence was followed by a deterioration in school performance. In Brazil, elementary education is divided into two stages. The first one includes from the first to the fifth grade, while the second stage comprise from the sixth to the ninth grade. Over the period covered by this research, most students advanced between grades and seven of 
them moved from the first to the second stage. This variable, whose possible effects have not been analyzed, may be one of the main factors responsible for the observed drop in performance. Note that in more advanced grades the content of the respective subject matters tends to be more complex than in the previous ones. This means an increase in attentional and cognitive demand on a student who is facing situations such as parent's divorce, distancing from the father, change of address, transfer of custody etc., all requiring adaptation and potentially causer of emotional and social effects.

The small number of cases included in the present study and the fact that they all belong to only two social strata with small differences, but both of them with low income, prevented the effects of socioeconomic level on academic performance from being observed. However, there is robust evidence that students belonging to higher social classes perform better than those from lower classes (Caprara, 2017).

In addition to the considerations above, there are indications that domestic violence is associated with problems psychological in nature, such as depression, low self-esteem, fear and aggression, already documented in the literature, as pointed out by Corrêa and Williams (2000), which can also interfere negatively in school achievement. The phenomenon analyzed here is multi-determined which makes it difficult to isolate the effects of a single variable as proposed in the present study. The design with repeated measures may be a viable alternative, but doing so by documentary research restricts the collection of data to those available in the original sources of information. Longitudinal studies with this type of design and the application of standardized tests would also be hard to perform, since information about families in which violence occurs is confidential and of restricted access. In view of these considerations, the adoption of designs between groups emerges as a viable alternative, with the possibility of using standardized tests, which allow greater control of variables and the production of more reliable data. In this case, the use of large samples is the best option to produce data with greater reliability and generality. On the other hand, it is a methodological option that makes research more expensive. Small samples make research cheaper, but the data generated is less robust.

Although breaking the cycle of violence was not enough to positively influence students' academic achievement, the results provided by this study can be useful for families facing this type of problem. They can also be useful for teachers, helping them to avoid assigning students derogatory and stigmatizing labels and, instead taking their poor performance as a possible indicator of family problems in the absence of other limiting factors. Above all, the phenomenon in question must be taken into account in the development of public policies that search for communication and integration between the systems of protection for women and education. Otherwise, it will be producing a kind of "Matthew effect", nurturing violence, since children who grow up in violent homes tend to reproduce it in their future relationships either as authors or as victims (Miranda, Paula and Bordin, 2010) and also promoting the perpetuation of social inequalities (Caprara, 2017).

\section{References}

Brancalhone, P. G., Fogo, J. C., \& Williams, L. C. A. (2004). Crianças expostas à violência conjugal: valiação do desempenho acadêmico. Psicologia: Teoria e Pesquisa, Brasília, DF, v. 20, n. 2 , p. 113-117, Maio/Ago. 2004. DOI: http://dx.doi.org/10. 1590/S0102-37722004000200003. Retrieved from: https://www.scielo.br/scielo.php?script=sci_arttext\&pid=S010237722004000200003

Caprara, B. M. (2017). Classes sociais e desempenho educacional no Brasil. (Doctoral dissertation). Retrieved from https://www.lume.ufrgs.br/handle/10183/172397

Corrêa, L. C., \& Williams, L. C. A. (2000). O impacto da violência conjugal sobre a saúde mental das crianças. In: REUNIÃO ANUAL DE PSICOLOGIA, 30., 2000, Brasília, DF. Psicologia no Brasil: diversidade e desafios: resumos de comunicações científicas. Brasília, DF: Sociedade Brasileira de Psicologia, 2000. p. 235. Retrieved from: https://www.sbponline.org.br/arquivos/2000.PDF

Ghazarian, S., \& Buehler, C. (2010). Interparental conflict and academic achievement: An examination of mediating and moderating factors. Journal of Youth and Adolescence, New York, v. 39, n. 1, p. 23-35, 2010. DOI: 10.1007/s10964-008-9360-1. Retrieved from: https://www.researchgate.net/publication/41103530_Interparental_Conflict_and_Academic_Ach ievement_An_Examination_of_Mediating_and_Moderating_Factors

Harold, G. T., Aitken, J. J., \& Shelton, K. H. (2007). Inter-parental conflict and children's academic attainment: a longitudinal analysis. The Journal of Child Psychology and Psychiatry, London, $\mathrm{v}$. 48, n. 12, p. 1223-1232, Dec. 2007. Retrieved from: https://www.ncbi.nlm.nih.gov/pubmed/18093028 
Miranda, M. P. M., Paula, C. S., \& Bordin, I. A. (2010). A violência conjugal física contra a mulher na vida: prevalência e impacto imediato na saúde, trabalho e familia. Revista Panamericana de Salud Publica, Washington, DC, v. 27, n. 4, p. 300-308, 2010. DOI: 10.1590/ S102049892010000400009. Retrieved from: https://www.scielosp.org/article/rpsp/2010.v27n4/300$308 /$

Rohenkohl, L. M. I. A., \& Castro, E. K. (2012). Afetividade, conflito familiar e problemas de comportamento em pré-escolares de famílias de baixa renda: visão de mães e professoras. Psicologia: Ciência e Profissão, Brasília, DF, v. 32, n. 2, p. 438-451, 2012. DOI: https://doi.org/10.1590/S1414-98932012000200012. Retrieved from: http://www.scielo.br/scielo.php?script=sci_arttext\&pid=S141498932012000200012\&lng=en\&nrm=iso

Waiselfisz, J. J. (2015). Mapa da violência 2015: homicídio de mulheres no Brasil. Brasília, DF: OPAS/OMS. ONU Mulheres; SPM; Rio de Janeiro: Flacso, 2015. Retrieved from: http://www.onumulheres.org.br/wpcontent/uploads/2016/04/MapaViolencia_2015_mulheres.pdf 